\title{
Strategic planning in the forest sector developed timber-producing countries as a key tool for the rational use of natural resources
}

\author{
Galina V. Astratova ${ }^{1,2, *}$, Natalia K. Pryadilina ${ }^{3}$, and Vladimir V. Klimuk ${ }^{4}$ \\ ${ }^{1}$ Ural Federal University named after the first President of Russia B. N. Yeltsin, Department of \\ Integrated Marketing Communications and Branding, 620002 Ekaterinburg, Russia \\ ${ }^{2}$ Ural Juridical Institute of MIA of Russia, 620057 Yekaterinburg, Russia, \\ ${ }^{3}$ Ural State Forest Engineering University, Department of Economics and Economic Security, 620100 \\ Yekaterinburg, Russia \\ ${ }^{4}$ Baranovichi State University, 225411 Baranovichi, Belarus
}

\begin{abstract}
The problem of rational use of resources is a priority for all mankind, which is confirmed by the presence of many national and interstate programs in the field of environmental management, resource conservation and improving the efficiency of environmental management. Forest complex play a special role in the rational use of natural resources. Forestry has a long process of reproduction, so a set of measures for the use, safety, integrity, reproduction of forests and the balance of the forest resources market conjuncture is necessary. A long-term national strategy is needed to achieve sustainable economic growth. Canada, Sweden, Finland, Latvia, Belarus, and China have national strategies for the forest sector development on 10-20-50 years. The strategic planning process in the forest sector is ambiguous and controversial; it includes the coordination of different interests of actors and economic-mathematical modelling, assessment of the effectiveness of environmental management and resource management. The research objective: strategic planning analysis in the above-mentioned countries forest complex in the context of natural resources rational using. The following factors were identified: the sequence of making economically significant decisions by the State; the strengthening role of the public in the decision-making process on the forest resources rational using.
\end{abstract}

\section{Introduction}

Rational resources using is a complex process involving the utilization of natural resources in volumes and ways that ensure the harmonization of communication between human and nature, sustainable economic development, optimal application of resource and natural potential, as well as effective economic mechanisms for environmentally safe use of natural resources. The problem of rational resources using is a priority for all mankind, which is confirmed by the presence of many national and interstate programs in the field of

* Corresponding author: galina_28@mail.ru 
environmental management, resource conservation and improving the efficiency of nature management $[1,2,3]$.

Forests play a special role in the issue of rational resources using, since "... the forest is one of the global factors for ensuring the sustainable development of mankind and the environmental safety of its life» [4, p. 171]. In this regard, the ecological and economic aspects of the forestry evolution as the leading tools for the sustainable development of the forest potential become particularly important. As the well-known forester, Professor Sergey V. Zalesov emphasizes: "The ecological aspect of sustainable forestry development involves the preservation of the environment, the biological diversity of forest ecosystems, the rational use of natural resources, the protection of the atmosphere, land, subsoil, forests, waters, the fight against desertification, the environmentally safe use of biotechnologies, etc. The economic aspect of forest management involves maintaining a balance of economic interests of the main subjects of forest relations: the State and the owner of forests, forest users, forest management bodies at all levels and the population» [4, p. 179].

Thus, the issue of the need to develop long-term plans and strategies for forest management becomes relevant.

For example, these can be economic and mathematical models of strategic forest management, focused on the relationship between decisions such as: planning for forest cultivation and harvesting, as well as sustainability and economic returns from forest management. Although the key theme of strategic planning is sustainable forest management with a particular focus on ecosystem management and a reduced focus on wood itself [5]. It is expected that strategic planning in the forest sector is carried out differently in different countries. That is why it is interesting to study international practice, especially in terms of economic results and efficiency of forest management.

It should be noted that most timber-producing countries with market economies make extensive use of State strategic planning for the long-term development of the national forest sector. In some cases, commercial strategies are used, but their share is not large [5].

So, forest planning in the world practice is implemented through two main types of programs:

1. Long-term (for a period of more than 20 years) regional forecasts of development of the forest sector that are engaged in international organizations (e.g. FAO, World Bank, the European Forest Institute and others);

2. National strategy (program) development of the forest sector.

For example, in Russia and Belarus, strategic planning in the forest sector is carried out at the State level. Thus, the Federal Law "On Strategic Planning in the Russian Federation", as well as the State Program "Belarusian Forest", creates a new legal framework for the organization of strategic forest planning at the state and regional levels.

In most developed forest-producing countries, the national forest policy of the State is the basis of the strategic planning system of the forest sector development. To determine the missions of the forest sector, strategic goals and objectives of its development, comprehensive studies of its state, and trends in changes in the main indicators are carried out using progressive statistical and economic-mathematical tools [5, 6, 7, et al.]. This makes it possible to develop scientifically based, agreed upon by all participants in forest relations, priority directions of the national forest policy [8,9].

At the same time, the process of a national forest policy developing or strategic planning in the forest sector is a very controversial and debatable activity, which includes not only the coordination of different interests of forest complex entities, but also economic and mathematical modeling, and the assessment of the effectiveness of environmental management and resource management. 
In this regard, the purpose of the study was to analyze strategic planning in the forest complex of developed forest-producing countries as a key tool for the rational use of natural resources.

\section{Application of strategic planning in the forest complex}

As it is well-known, the system of strategic planning in the forest complex includes the development of national target strategies (programs, plans) for the elaboration of the forest sector. The methodology and algorithm for developing target strategies (programs, plans) contains an analytical part, predictive studies, and implementation mechanisms. Each stage contains sections covering all the structural components of the forest sector along the technological chain.

The European Union is the first to design a unified strategy for the sustainable development of the forest sector of the economy. The EU Forestry Development Strategy was elaborated in conjunction with other branches of the forest sector, including the forest industry, scientific and technical support, transport, services and R\&D segments. The strategy for the sustainable development of the EU forest sector includes a wide range of issues, such as: rural development, environmental protection, trade flows of forest products on domestic and foreign markets, scientific research, industrial and energy policy, and the development of cooperation between EU member States. Interaction between the branches of the forest sector is considered as the most important condition for the development of innovative activities. Considerable attention is paid to the issues of social and environmental sustainability of the forest sector [6].

The EU Member States are responsible for the development and implementation of forest policies within a clearly defined framework and on the basis of national laws based on long-term planning. The main regulatory document in the EU forest sector is the "New EU Forest Strategy: for the Sake of Forests and the Forest Sector" (Forest Strategy 2013). The duration of the new strategy is not limited, but many targets are set for the period up to 2020 [6].

The main principles of the Forest Strategy 2013 are: sustainable management and use of forests; resource efficiency and global responsibility. Currently, specialized software products are being developed to automate the process of planning multi-purpose forest management, collecting information from stakeholders, and finding a compromise between stakeholders in making optimal decisions [6].

As the leading forest countries of the European Union, consider Finland, Sweden, Latvia and Belarus.

Finland. The forest sector accounts for about $4.1 \%$ of the country's GDP. Forests cover $76 \%$ of Finland's territory, i.e. 26 million hectares. The total reserve of wood on the root is 2.3 billion $\mathrm{m}^{3}$. Forest productivity on average per hectare is growing annually. The volume of harvesting ranges from 50 to 55 million $\mathrm{m}^{3}$. The forest sector accounts for $20 \%$ of the country's industrial production; its share in exports is $37 \%$.

According to the form of ownership, the forests of Finland are distributed as follows: private owners own $52 \%$ of the forest land, timber companies is $8 \%$, the state $-35 \%$, others (municipalities, etc.) $-5 \%$.

Forestry and the Finnish forest industry are traditionally the leading sectors of the Finnish economy.

Initially, the issues of increasing forest productivity were addressed in the national forest programs TYCHO (1961), MEASURE I (1964, twice adjusted) and MEASURE III (1969). All of these programs were of a long-term and alternative nature. 
The National Forest Strategy of Finland until 2025, adopted in 2014 and in force, contains the main directions of the Finnish forest policy. Regional forest programs have been developed at the regional level, taking into account their long-term development.

The Finnish Forest Center (Metsäkeskus) is responsible for developing regional forest plans and, at the request of the forest owner, forest plans at the forest estate level. In private forests, forest management can also be carried out by entrepreneurs practicing in the field of forest services, forestry associations, and the commercial division of the Finnish Forest Center.

Strategic forest management planning in Finland's publicly owned forests is based on the conservation of forest diversity and sustainability. For planning at the local level, the materials of forest management are used; for planning at the regional level, the materials of the state forest inventory are used.

The successful implementation of the strategy can be traced back to Finland's wellestablished forest statistics, which attests to their forestry validity and high efficiency. It is also important that the strategic planning process is open to the public. In the strategic documents for the development of the country' forest sector, special attention is paid to environmental, economic and social aspects [6, 10-15].

Sweden. The forest sector accounts for about $4 \%$ of the country's GDP. Forests cover $53 \%$ of the territory of Sweden, i.e. 23.5 million hectares. The total reserves of wood at the root are 2.9 billion $\mathrm{m} 3$. The volume of harvesting ranges from 65 to 70 million $\mathrm{m}^{3}$. The forest sector accounts for $8 \%$ of the country's industrial production; its share in exports is $15 \% .76 \%$ of Sweden's forests are privately owned.

The goal of strategic planning of the forest sector development in Sweden is to ensure effective forest management, conservation and sustainable use of forests, and the sustainable development of all forest industries based on the processing of forest resources.

The Forecasting Department of the National Forestry Council of Sweden is responsible for the collection and analysis of information and the calculation of forecast indicators, on the basis of which decisions are made at all levels of government. It also organizes and coordinates the necessary research on forest planning at different levels of forest management, taking into account national goals.

Based on the data from the State forest inventory in Sweden, strategic planning of forest management is carried out. The inventory data is updated every five years. This allows you to accurately know and monitor in detail the state of the forest stands of the territory and competently plan forestry activities.

Forest inventory and strategic forest planning materials are available to all interested parties.

It should be noted that the existing practice of preserving biological diversity and water bodies in the planning and implementation of forestry activities in Sweden and Russia is different, as are the issues of its legislative regulation. In Russia, the most important issues are the practical issues of conservation of environmental values in industrial timber harvesting and planning of forest management activities taking into account the environmental characteristics of the territory. This is especially important when implementing an intensive forestry model. The Swedish experience in this sense can be a basis and an example for developing best practices that can be adapted to Russian conditions and refined [13, p. 41-42].

Latvia. The forest sector accounts for about $6.5 \%$ of the country's GDP. Forests cover almost $50 \%$ of the territory of Latvia, i.e. 3.58 million hectares. The total stock of wood on the root is 668 million $\mathrm{m}^{3}$. The volume of harvesting is $10-12$ million $\mathrm{m}^{3}$ of wood annually. The forest sector accounts for $27 \%$ of the country's industrial production; and $75 \%$ of the forest sector's output are exported. 
According to the form of ownership, the forests of Latvia are distributed as follows: $47 \%$ of the forests belong to the State and are managed by the State joint stock company "Latvian State Forests"; 49\% are private forests; 4\% - other forests (municipalities, etc.).

The policy of the Government of the Republic of Latvia is aimed at the long-term development of forestry, which is the main factor for the success of the industry. National Program for the Development of the Forest Sector and Related Industries to promote the development of more efficient use of timber and ensure the long-term development of this sector. The program is being implemented with the support of the Food and Agriculture Organization of the United Nations [11].

The use of forecasting and planning methods in drawing up a scenario for the forestry development in Latvia, which is based on the program-target method, allows taking into account not only the quantitative results obtained, but also other aspects of the industry component, such as the legislative framework, the industry management system, and others. This allows displaying the integrity of the impact of various constituent factors on forecasts within the sector.

The positive actual results of the implementation of the scenario, both in the short and long term, indicate the possibility of using the production function to develop scenarios for the stabilization and development of other sectors of the economy.

The strategic objectives of the forestry development and forest industries are closely interrelated. The long-term goal of forestry development is to increase the value of forest capital. The general goal includes the following specific goals: increasing productivity and improving the quality of forests, increasing sustainable forest management, preserving biodiversity, and ensuring the environmental sustainability of forests. The achievement of the above-mentioned goals is designed to provide a raw material base for increasing the efficiency of wood processing, increasing the production of goods with high added value.

Currently, the functions of state management of forests of all forms of ownership are carried out by two departments of the Ministry of Agriculture of the Latvian Republic, as well as the State Forestry Service [6, 10-15].

Belarus. In the Republic of Belarus, forests are one of the main renewable natural resources and the most important national wealth. Forests and forest resources are of great importance for the sustainable socio-economic development of the country, ensuring its economic, energy, environmental and food security. According to a number of key indicators that characterize the forest fund (forest cover, forest area and the stock of growing wood per inhabitant), Belarus is among the top ten forest states in Europe. According to the Ministry of Forestry of the Republic of Belarus, the share of forest cover in the country increased from $21.5 \%$ in 1945 to $40.1 \%$ in 2020 . The forest fund of the Republic of Belarus is 96.8 thousand hectares. In 2020, 10.8 million $\mathrm{m}^{3}$ of business wood was sold to the domestic market of the country and 0.5 million $\mathrm{m}^{3}$ for export up from $\$ 180$ million in 2015 to $\$ 180$ million in $2020[16,18]$.

Economic relations in the forest sector of Belarus are characterized by the following main features, such as:

- Connection State and economic functions in the system of the forestry sector and financial flows presented budget funds to perform the functions of protection, forest protection, etc.;

- Lack of competitive market environment in forestry and forest management [17].

It was also considered necessary to briefly focus on such forest countries as Canada and China.

Canada. The forest sector accounts for 3\% of the country's GDP. Forests cover almost $45.3 \%$ of the territory of Canada, i.e. 417.6 million hectares. A total reserve of wood on the root is 26 billion. $\mathrm{m}^{3}$ [10]. 
The volume of harvesting annually amounts to $150-160$ million $\mathrm{m}^{3}$ of wood. The forest sector accounts for $17.2 \%$ of the country's industrial production. About $11 \%$ of the forest sector's output is exported; $93 \%$ of the forests in Canada are State-owned (of which $71 \%$ are provincial property and $23 \%$ are managed by federal and territorial authorities); $6 \%$ of the forests are privately owned [19].

In 1980, systematic work was initiated in Canada to justify a National Forest Strategy. The first strategic developments in the forest sector of the Canadian economy were calculated for the period from 1981 to 1987. Since then, every five years, the strategy for the forest sector development of the economy makes the necessary adjustments to take into account new trends and patterns caused by scientific, technical, economic, social, and environmental elaboration at the global and national levels. Each new version of the strategy represents another step on the road to sustainable social, economic and environmental development of the forest sector and to promote Canada's image as a leader in sustainable forest management.

An international working group on forest issues has been established, whose main task is to monitor trends in the elaboration of the global forest sector and develop proposals for the improvement of the Canadian forest sector on this information basis.

Exploring emerging promising global and regional markets and gaining leadership is one of the strategic goals of the Canadian forest sector. Exports of high-value-added goods and non-wood products are growing faster than exports of traditional forest products, which is facilitated by the creation of conditions for increasing the production of high-value-added forest products [21].

China. The forest sector of the PRC forms about $4.8 \%$ of the country's GDP. Forests cover almost $21.65 \%$ of the territory of China, i.e. 208 million hectares. A total reserve of wood at the root is 15137 million $\mathrm{m}^{3}$. The volume of harvesting annually amounts to 160 170 million $\mathrm{m}^{3}$ of wood.

In the People's Republic of China, forests are the property of the State, except for forests that are collectively owned. The latter are State-owned forests owned by a group of people with the right to use for 30-70 years and the possibility of extending the term of use [20].

China has relatively limited forest resources and, at the same time, enormous opportunities for territorial distribution of production, which meant using local advantages and achieving maximum results based on the availability of natural resources and existing technical and economic conditions, and contributed to a rational division of labor between the coastal and inland regions of the country.

Strategic forest planning, management of forest resources and coordination of timber production in China is carried out by the state. Through a series of major environmental reforestation projects, such as the natural forest conservation program, mandatory tree planting throughout the country, and the fast-growing and high-yielding business forest base development program in timber-producing areas, China has achieved an increase in forest area and forest reserves, and has become one of the countries with the fastest growth in forest resources in the world. According to the national program, in 2021, the country's forest cover should be $23 \%$, and the forest resources reserves should be 16.5 billion $\mathrm{m}^{3}$ respectively [20].

China's forestry management develops taking into account the accumulated traditions of the planned economy and adapting them to the challenges of the time; the principle of partisanship in forest management is clearly traced, which is expressed in making management decisions taking into account the dominant communist ideology; the country has a dual structure of forest management-departmental and political; the decisions of the Communist Party of China are mandatory in forest management, which allows to quickly respond to changes both within the country and in international markets and not wait for changes in forest legislation; China's forest policy is aimed at saving the country's forest 
resources, intensive forestry management and stimulating deep processing of wood [20, 21].

In recent years, China has been actively applying Canadian technologies in forestry management [20].

\section{Discussion}

With comparable efficiency of the forest sector, the forms of forest resources ownership in advanced countries are different. Thus, in Finland and Sweden, private forest ownership dominates; in Latvia, approximately $50 \%$ are State forests, $50 \%$ are private; in Belarus, "forests are the exclusive property of the state" [18]; in Canada, most of the forests belong to the provinces or are in federal ownership; in China, forests are State property, except for those forests that are in collective ownership.

An analysis of the above-mentioned countries development strategies of the forest sectors showed that, despite the existing differences, they have some common features:

* Their development is initiated, as a rule, by the government of the country and focuses on State support for the forest sector;

* Forecasts are developed on the basis of scientific analysis of the situation and research using balance calculations and modern economic and mathematical tools;

* Timely updating of strategic planning documents is provided;

* One of the main principles of strategic planning is to improve the efficiency of the entire forest sector, including the forestry and timber industry, as well as related sectors;

* Formation of effective financial mechanisms to ensure the protection of forest resources reproduction, development of the market of works and services in this area;

* The activities in the strategic planning documents are targeted, resource-based, addressed and subject to external monitoring and control;

* The strategies take into account the requirements of sustainable forest management adopted by international communities, including rational forest management and the legality of the wood origin, certification of forests and forest products;

* Strategic developments are integrated and coordinated and take into account the interests of all participants in forest relations;

* In addition to economic issues, the strategies identify their social and environmental components;

* Strategies provide a large amount of research and development in the forestry sector, including forestry, logging, timber transportation, taking into account environmental requirements, creating an effective and competitive technologies of wood processing, forest products sector with high added value.

\section{Conclusion}

As foreign experience shows, only consolidated management and planning can ensure the effective functioning of the forest sector. It is impossible to achieve sustainable economic growth based on the rational use of natural resources without a long-term strategy [22]. For example, In Russia, the most important issues are the practical issues of conservation of environmental values in industrial timber harvesting and planning of forest management activities taking into account the environmental characteristics of the territory. This is especially important when implementing an intensive forestry model [23].

With years of development experience working on long-term strategies for the forest sector, the above-mentioned countries can advance to identify the main changes in the external environment, such as changes in the structure of demand for individual forest 
products, degradation of forest resources, increasing demand for environmental services of the forest, stricter environmental regulations.

The national planning system for the forest sector development is formed in these countries not only on long-term forecasts, but also long-term plans, forest management projects and operational plans, the development of which is systematic. In industrialized countries with advanced forest sector significant decisions at the State level are accepted in the following sequence: first, a national forest policy, which determines the strategy of actions on its basis, was adopted adequate legislation, and then, on the basis of their forest develops strategic programs to different coordinated levels of control. This applies generally to all forests with different forms of ownership. And although these documents were developed with the participation of representatives of all subjects of forest relations, nevertheless, the leading role was initially shown by the leadership of the State, which acted as the initiator, organizer and coordinator of public forces. At the initial stage, the technocratic style of strategic decision-making prevailed, in a narrow circle of the bureaucratic apparatus, which was then replaced by a corporate one, that is, with the participation of the main players in the market economy, i.e. representatives of forest owners, timber companies, banking structures, forest management bodies, and the scientific community. Under the growing influence of social forces, including various nongovernmental organizations, in recent years, the participation of representatives of all sectors of society has become increasingly important; so that decisions taken take into account the most important public interests for the rational use of natural resources.

\section{References}

1. G.V.Astratova, V.V.Klimuk, O.A.Ruzshitskaya, I.V.Ivliev, A.Ruchkin, N.Yurchenko, J. of Env. Man. and Tourism (JEMT), 10.7(39), 1667-1677 (2019)

2. G. V.Astratova, O. A.Ruzshitskaya, Rus. J. of resources, conservation and recycling, 3(4), 04RRO416 (2016)

3. V. M.Zolotukhin, V. A.Gogolin, M. Yu.Yatsevich, M. I.Baumgarten, A.V. Diaghileva, Ecology and safety in the techno sphere: actual problems and solutions. IOP Conf. Series: Earth and Environmental Science, 50, 012 (2017)

4. Quality of life: yesterday, today, tomorrow. Actual problems of Russia's accession to the WTO. Scientific monograph. Under the general and scientific editorship of Doctor of Economics, Professor G. V. Astratova (Publishing house of the GC "Positive Strategy", Yekaterinburg, 2012)

5. E. A. Gunn, In: A. Weintraub, C. Romro, T. Bjornal, R. Epstein and J. Miranda, Eds., Handbook of Operations Research in Natural Resources, 317-341 (Springer, New York, 2007)

6. E. V.Lopatin, Research on the development of integrated forest management in the countries of the European Union (WWF of Russia, Moscow, 2016)

7. A.P. Petrov, State forest management (VIPCLK, Pushkino, 2011)

8. N.Shmatkov, E.Kulikova, Sust. forest man., 1 (30), 2-9 (2012)

9. National Forest Policy Statement. A New Focus for Australia's Forests. (Commonwealth of Australia, 1995)

10. A. A. Nikolaichuk, O. A. Nikolaichuk, Problem Analysis and State-Management Design, 3, 103-114 (2013)

11. N. K. Pryadilina, Innovazii I investizii, 2, $71-75$ (2018) 
12. I. I. Leonovich, N. P.Vyrko, M. N. Demidko, Proceedings of BSTU. Forestry and woodworking industry, 2, 37-40 (2014).

13. D.Lugovaya, Sust. Forest Man., 2(58), 36-44 (2019).

14. E. I. Babbel, Proceedings of BSTU, 2(140), 82-85. (2011)

15. N. A. Lukashuk, Proceedings of BSTU, 7, 33-37 (2016)

16. Official website of the Ministry of Forestry of the Republic of Belarus. [Electronic resource]. // Access Mode: https://mlh.by/

17. T. V. Kashtelyan, Trajectory of Science, 4 (9), 276-288. (2016).

18. Forest Code of the Republic of Belarus. Article 5 (2000)

19. Perspective research on the forest sector of North America. Overview, Forestry and Hunting, 2 (2015).

20. V.Petrov, A.Bespalko, Chen Lijun, LesPromInform, 1 (115), 140-144 (2016)

21. G.V. Astratova, Russian Journal of Resources, Conservation and Recycling, 4(6), 12ECOR419 (2019)

22. Jordi Garcia-Gonzalo, J.G. Borges, Forest Policy and Economics, 103, 1-3 (2019)

23. Strategy for the development of the forest complex of the Russian Federation until 2030. (2012). Approved by the decree of the Government of the Russian Federation of September 20, 2018 No. 1989-R 